\title{
Variation of nuclear DNA content in seeds of Nitraria schoberi L.
}

\author{
Maria Voronkova ${ }^{1, *}$, Evgeniy Banaev ${ }^{1}$, Maria Tomoshevich $^{1}$, and Taigana Ak-Lama ${ }^{1}$ \\ ${ }^{1}$ Central Siberian Botanical Garden of the Siberian Branch of the Russian Academy of Sciences, \\ 630090, Novosibirsk, Russian Federation.
}

\begin{abstract}
For the first time are search of nuclear DNA relative content in Nitraria schoberi L. seeds from 15 natural populations of Siberia, the Crimea, Kazakhstan, and Tajikistan has been conducted by the method of flow cytometry. High intra- and interpopulational variations of nuclear DNA content - 2,93-3,39 pg, at average value - 3,22 $\pm 0,108$ pg is revealed.
\end{abstract}

\section{Introduction}

The assessment of intraspecific variation of a genome size helps cognition of evolution pattern and species adaptation, way soft heir divergence, and solving systematic issues in complex taxonomic groups [1, 2]. Nitraria L. species are typical halophytes, their populations are often small and isolated since they are restricted to intrazonal communities. Nitraria schoberi L. Is the most polymorphic species, it is characterized by mixoploidy and variability of chromosome numbers which may be one of the factors of plant adaptation to habitat extreme conditions [3, 4].

The aim of the work was study of relative content of nuclear DNA in N. schoberi in different habitats within the natural range.

\section{Materials and Methods}

\subsection{Plant materials}

The content of nuclear DNA was determined in N. schoberi dormant seeds. As an internal standard were used fresh leaves of Raphanus sativus L. 'Saxa' ${ }^{32}$ (2C DNA content $=1,11$ pg) seeds of which were received from the Centre of Plant Structural and Functional Genomic, Institute of Experimental Botany, Academy of Sciences of the Czech Republic, Olomouc[5].

Research was conducted in 15 natural populations of Siberia, the Crimea, Kazakhstan, and Tajikistan (Figure 1). For the analysis of an endogenic form of variation, 4 model plants were selected in three populations (№ 5, 11, 15), 6 seeds from each plant were analyzed. For the analysis of intrapopulational variation, seeds were collected not less than

*Corresponding author: $\underline{\text { bmc_87@mail.ru }}$ 
from 10 plants in each of the populations. Seeds were collected by the authors of the article in 2009-2017, they are stored in CSBG SB RAS.

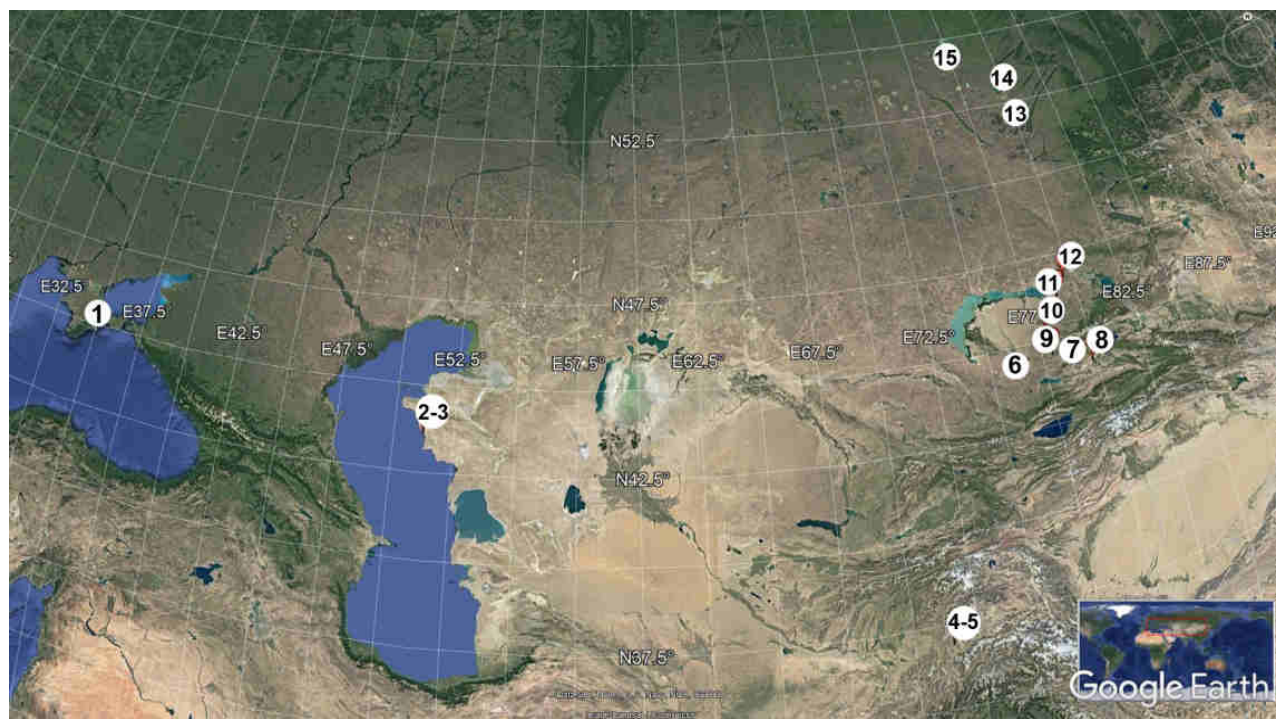

Fig. 1. Collection sites of the plant material. 1-15 - numbers of populations.

\subsection{Flow Cytometry}

All measurements were performed in Central Siberian Botanical Garden, SB RAS (Novosibirsk). DNA content of $N$. schoberi plants was determined by the method of flow cytometry using staining of isolated nuclei with propidium iodide (PI). The analysis was performed on Cy Flow Space (Germany, Sysmex Partec) with a laser radiation source of $532 \mathrm{~nm}$. The procedure of the work in detail was given by us earlier [6].

\subsection{Statistical analysis}

Basic statistics (mean, standard deviation, genome size variation) were calculated in R [7].

\section{Results}

The analysis of endogenic variations showed sufficiently high variability of relative DNA content in $N$. schoberi seeds. The greatest stability was revealed in model plants of population №15 growing in the vicinities of Bagan Lake, Novosibirsk Oblast - 3,28-3,39 pg (genome size variation (V) - 0,24-0,39\%). In the populations of Tajikistan (№5) and Kazakhstan (№11) DNA content in seeds of one plant changed within 3,09-3,32 pg and $3,18-3,34 \mathrm{pg}$, respectively, $\mathrm{V}=0,25-1,44 \%$. The data obtained on variation of DNA content in seeds collected from one plant correlated with intrapopulational variability of DNA content (Table). So minimum intrapopulational variation was found in population № 6 (Kazakhstan) - 0,39 \% and maximum one - in population № 5 near the Pyandzh River (Tajikistan) - 1,56 \%. In this regard it should be noted that seeds collected from one bush may have a male hametophyte from the other plant, and consequently the results obtained may be manifestation of intrapopulational variation. Interpopulational variation of DNA content in N. schoberi seeds amounted to 3,35\%. 
Table 1. Intrapopulational variation of the relative DNA content in N. schoberi seeds

\begin{tabular}{|c|c|c|c|c|c|c|}
\hline $\begin{array}{c}\text { № of } \\
\text { population }\end{array}$ & $\begin{array}{c}\text { Quantity } \\
\text { of } \\
\text { studied } \\
\text { samples }\end{array}$ & $\begin{array}{c}\text { 2C DNA content } \\
\text { (pg) } \\
\text { average value }\end{array}$ & $\mathrm{SD}^{*}$ & Min & Max & $\mathrm{V}^{\text {** }, \%}$ \\
\hline 1 & 10 & 3,09 & 0,017 & 3,06 & 3,11 & 0,55 \\
\hline 2 & 10 & 3,23 & 0,015 & 3,21 & 3,25 & 0,46 \\
\hline 3 & 10 & 3,20 & 0,020 & 3,16 & 3,23 & 0,63 \\
\hline 4 & 10 & 3,25 & 0,016 & 3,22 & 3,26 & 0,49 \\
\hline 5 & 36 & 3,21 & 0,050 & 3,09 & 3,32 & 1,56 \\
\hline 6 & 10 & 3,07 & 0,012 & 3,05 & 3,09 & 0,39 \\
\hline 7 & 10 & 3,32 & 0,015 & 3,30 & 3,34 & 0,45 \\
\hline 8 & 10 & 3,27 & 0,027 & 3,23 & 3,30 & 0,83 \\
\hline 9 & 10 & 3,17 & 0,019 & 3,16 & 3,21 & 0,60 \\
\hline 10 & 10 & 2,97 & 0,013 & 2,95 & 2,99 & 0,44 \\
\hline 11 & 24 & 3,25 & 0,040 & 3,18 & 3,34 & 1,23 \\
\hline 12 & 10 & 2,98 & 0,031 & 2,93 & 3,02 & 1,04 \\
\hline 13 & 10 & 3,21 & 0,032 & 3,16 & 3,27 & 1,00 \\
\hline 14 & 10 & 3,22 & 0,035 & 3,16 & 3,28 & 1,09 \\
\hline 15 & 30 & 3,34 & 0,036 & 3,28 & 3,39 & 1,08 \\
\hline Average & 210 & 3,22 & 0,108 & 2,93 & 3,39 & 3,35 \\
\hline value & & & & &
\end{tabular}

*SD - standard deviation, ${ }^{* *} \mathrm{~V}$ - genome size variation

\section{Discussion}

Occurrence of intraspecific variation of the genome size in various taxa was presented in a number of works, however, the results obtained were often refuted by replicate experiments for various reasons - the international interior standards were not used, availability of secondary metabolites preventing staining was ignored [2]. Such reports led to scepticism of reliability of any data on intraspecific variation of DNA content. Study of intraspecific genome size variation became again popular when the technique of experiments was improved and flow cytometry was widely adoptedas an analytical method [8-10].

It is assumed that changes in the genome size may be related to species divergence, different environmental conditions, development stages touched on various populations or certain plants [11-15]. It should be noted that variation of $2 \mathrm{C}$ values determined by heterochromatin polymorphism, B-chromosomes, polyploidy or hybridization is well understood and is not exceptional for the species of angiosperms [2].

Our research showed that nuclear DNA content in $N$. schoberi seeds varied on the same level within both one plant (from 1,03 to 1,08 times) and a population (from 1,01 to 1,08 times). Extreme variants within the whole studied range differed in DNA content by 1,16 times. We did not reveal here with dependence of DNA content in plants on geographical position of populations or habitat conditions. The most likely explanation of variability of DNA content in N. schoberi seeds is a widespread aneuploidy in the genus Nitraria [16]. Karyological study showed that there was no certain number of chromosomes in $N$. schoberi cells, only the most frequently encountered $2 \mathrm{n}=4 \mathrm{x}=48[3,4,17]$. In a number of works was noted influence of aneuploidy on the genome size and shown that the method of cytometry was sensitive and informative enough for detection of that phenomenon [18, 19]. Further more thorough study of Nitraria species, including karyology of N. schoberi plants 
in different populations, and comparison of the data obtained with the results of cytometry are needed.

The study was supported in part by the Russian Foundation for Basic Research (grant 16-04-00631 to E.V. Banaev).

\section{References}

1. P. Smarda, P. Bures, Preslia -Praha 82, 41-61 (2010)

2. J. Greilhuber, Ann. Bot. 95, 91-98 (2005)

3. E. N. Muratova, O. V. Goryachkina, E. V. Banaev, Turczaninowia 16, 50-54 (2013). In Russ.

4. I.Tarnavshi, Bul. Gradini Bot. al Muz. Bot. Univ. din Cluj. 28, 1-130 (1948)

5. J. Doležel, S. Sgorbati, S. Lucretti, Physiol. Plant 85, 625-631 (1992)

6. E. V. Banaev, M. A.Tomoshevich, M. S. Voronkova, Bot. Pacifica 7, 89-92 (2018)

7. R Development Core Team. R: a language and environment for statistical computing. (Vienna, 2011) http://www.R-project.org

8. J. Doležel, J. Bartoš, Ann. Bot. 95, 99-110 (2005)

9. J. Doležel, J. Greilhuber, J. Suda, Flow cytometry with plant cells: analysis of genes, chromosomes and genomes (Wiley, Weinheim, 2007)

10. J. Greilhuber, Ann. Bot. 101, 791-804 (2008)

11. H. J. Price, K. L. Chambers, K. Bachmann, Bot. Gaz. 142, 415-426 (1981)

12. A. Cavallini, L. Natali, Caryologia 44, 93-107 (1991)

13. L. Natali, A. Cavallini, G. Cionini, O. Sassoli, P. G. Cionini, M. Durante, Theor. Appl. Genet. 85, 506-512 (1993)

14. H. J. Price, J. S. Johnston, Proc. Natl. Acad.Sci. USA 93, 11264-11267 (1996)

15. J. Loureiro, E. Rodriguez, J. Doležel, C. Santos, Ann. Bot. 98, 515-527 (2006)

16. E. N. Muratova, O. V. Kvitko, E. V. Banaev, J.-Q. Zhang, G.-Zh. Wang. Bot J 96, 108115 (2011). In Russ.

17. G. Reese. Flora. 146, 478-487 (1958)

18. M. Pfosser, A. Amon, T. Lelley, E. Heberle-Bors, Cytometry 21, 387-393 (1995)

19. N. Roux, A. Toloza, Z. Radecki, F. J. Zapata-Arias, J. Doležel, Plant Cell Reps. 21, 483-490 (2003) 